REVISTA DE DERECHO UNED, núm. 5, 2009

\title{
CRISIS DE LA ADMINISTRACIÓN DE JUSTICIA
}

\author{
ALFONSO SERRANo GÓMEZ \\ UNED
}

Se recogen en este trabajo unas consideraciones generales, especialmente en el campo penal, relacionadas con la delicada situación en la que se encuentra nuestra Administración de Justicia, a fin de que la conozcan los jóvenes estudiantes de Derecho que próximamente se incorporen a la abogacía u otras profesiones, incluida la carrera judicial. Los que en breve inicien sus estudios por el nuevo sistema del plan Bolonia es probable que salgan peor preparados de la Universidad, lo que redundará de forma negativa en su formación profesional cualquiera que sea ${ }^{1}$, así como en la función social que han de desempeñar. Nuestra Universidad con escaso prestigio internacional ${ }^{2}$ seguirá deteriorándose, así como la capacidad científica de muchos de sus profesores debido a la falta de un sistema riguroso de selección ${ }^{3}$. De otra

${ }^{1}$ En las XXVIII Jornadas de las Escuelas de Práctica Jurídica, celebradas en mayo de 2009, con respecto al nuevo Grado en Derecho y la formación inicial del abogado se puso de manifiesto "La problemática de la implantación del Plan de Bolonia». Revista del Consejo General de la Abogacía Española. Abogados, núm. 56, 2009, pág. 41.

2 Según el ranking elaborado por The Times sobre las 500 mejores Universidades del mundo, la Universidad de Barcelona aparece en el puesto 186. En la clasificación de la Universidad Jiao Tong de Shangai sobre las primeras 500 universidades, la Universidad de Barcelona figura en el puesto 167, la siguiente en el 245. En el informe elaborado por el CSIC, la primera Universidad española que aparece clasificada es la Autónoma de Barcelona, en el puesto 263, le siguen Zaragoza (290), la Politécnica de Madrid (297) y la Complutense (300). Aunque hay diferencias en las distintas valoraciones lo cierto es que nuestras Universidades aparecen mal clasificadas.

${ }^{3}$ OLLERO, A., en Qué hemos hecho con la Universidad. Cinco lustros de política educativa, Madrid, 2007, escribe sobre la selección del profesorado «Concursos clandestinos», en pág. 446: "Por no haber no habrá ni pruebas públicas, circunstancia desconocida en cualquier otro cuerpo de funcionarios. Si bien la ley alude a "los principios de publicidad, mérito y capacidad", en los que el sistema de "Acreditación" se 
parte, los fondos que se dedican a la investigación son muy bajos y están mal distribuidos ${ }^{4}$.

En cuanto a la Justicia nos encontramos ante un entramado tan complejo que no es fácil enderezar lo que se ha torcido en el último cuarto de siglo. En este sistema no participan sólo los jueces y magistrados aunque son el eje central. En todo caso hay que tener en cuenta a los secretarios judiciales y resto del personal que trabaja en los Juzgados, abogados, policía, e incluso a la administración penitenciaria. También la Fiscalía tiene un papel muy importante, pero mientras no desaparezca su dependencia jerárquica y en cada Juzgado exista un fiscal con plena autonomía, en algún caso podrá ponerse en duda su imparcialidad ${ }^{5}$.

Teniendo en cuenta el deterioro en que se encuentra el sistema en su conjunto, difícilmente podrán hacerse avances medianamente importantes. Los problemas no se solucionan con el aumento de personal, que es necesario, o mejorando los medios materiales, sino con unos buenos jueces, seleccionados por un sistema riguroso, evitando la tentación de otras formas de ingreso donde juegue la politización, como sucedió con la Ley Orgánica del Poder Judicial de 1985 donde

refiere, lo primero no pasa de ser pura muestra de mala conciencia. No sólo no hay publicidad alguna sino que ni siquiera se produce contacto presencial entre la comisión (cuyo sistema de nombramiento la ley oculta pudorosamente...) y los candidatos. Éstos no podrán mostrar o argumentar méritos ni exhibir capacidad alguna. Se limitarán a enviar a la Comisión su acervo documental». Sobre esta cuestión me he ocupado en otra parte, en la 12. ${ }^{\text {a }}$ edición de esta obra, 2007, págs. XXXIII y ss., bajo el título «La selección del profesorado en la Universidad es un sistema corrupto dentro de los más corruptos».

4 Según el informe de la Fundación Cotec de 2007, la situación de la ciencia española a nivel mundial, sobre gasto en $\mathrm{I}+\mathrm{D}$, figura a la cola de los principales países europeos. En 2004 el tanto por ciento del PIB fue del 1,1, frente al 3,7 en Suecia, Japón $(3,2)$, Estados Unidos $(2,7)$, Alemania $(2,5)$, Francia $(2,2)$. La media de los países de la UE era del 1,9. Es frecuente en España conceder proyectos a profesores que no están capacitados para investigar, por lo que es un dinero perdido. En el Proyecto de Ley de los Presupuestos Generales del Estado para 2010 se disminuye la cantidad destinada a investigación respecto del año 2009. La asignada al Ministerio de Ciencia e Innovación se reduce en un 15\%. Es el Ministerio con mayor recorte presupuestario, lo que pone de manifiesto que la investigación le interesa poco al Gobierno. Esto no debe sorprendernos teniendo en cuenta la deficiente formación que tienen la mayoría de nuestros políticos. Se confirma lo que decía Unamuno: que «investiguen ellos» (Del sentimiento trágico de la vida en los hombres y en los pueblos, 1913, en ed. de 1999, pág. 272).

5 NIETO A., El desgobierno de lo público, Madrid, 2008, en pág. 311 escribe: «Hay fiscales que, cumpliendo instrucciones superiores, intervienen descaradamente en unos sumarios para paralizar la actuación del instructor, mientras que en otros casos atacan sin cuartel hasta cobrarse la pieza». Vid. infra nota 31. 
se estableció el procedimiento de ingreso por los conocidos tercer y cuarto turnos hoy reducido a uno ${ }^{6}$ en base a unos méritos discutibles. Por este sistema se incorporaron a la judicatura personas relacionadas con los partidos políticos ${ }^{7}$. Es fundamental disponer de personal competente, sin perjuicio de hacer las reformas legales pertinentes. También los abogados han de colaborar, no sólo con una buena preparación profesional, sino evitando entorpecer o retrasar el funcionamiento de la Justicia con escritos inútiles o sin fundamento.

Es posible que la Administración de Justicia se deteriore todavía más, en lugar de mejorar. Teniendo en cuenta la evolución de las transferencias conferidas a las Comunidades Autónomas, es probable que en un periodo no muy lejano lleguen a tener su propia Administración de Justicia, participando en el nombramiento de jueces y altos cargos; también pueden llegar a controlar la policía y administración penitenciaria. Así las cosas, los caciques de las autonomías tendrán más competencias y control en el campo de la Justicia; probablemente habrá mayor politización de ésta, disminuirá la independencia judicial y se degradará la democracia. Ya hay Comunidades Autónomas donde la policía y la Justicia tienen muchas dificultades para poder intervenir por el férreo control que tienen los políticos sobre personas y medios de comunicación que podrían denunciar hechos de corrupción de trascendencia penal ${ }^{8}$. Los profesionales del Derecho tendrán que padecer muchas desilusiones, como consecuencia de que las normas pueden interpretarse de muchas maneras, siempre que se pretenda retorcer su verdadero sentido, para beneficiar o perjudicar a personas concretas. La profesión de abogado no es fácil, no sólo por la complejidad del Derecho y el procedimiento a seguir ante jueces y tribunales, sino también porque a veces hay que soportar los abusos cometidos por algunos jueces; en estos casos los abogados normalmente no se atreven a denunciarles o formular la protesta correspondiente, pues temen posibles represalias que pueden perjudicar a sus clientes. La desconfianza en los jueces y policías ante el

${ }^{6}$ Dispone el párrafo cuarto del art. 311.1 de la LOPJ que una de cada cuatro vacantes en la categoría de magistrado «se proveerá por concurso, entre juristas de reconocida competencia y con más de 10 años de ejercicio profesional...».

7 DÍAZ HERRERA, J., y DURÁN. I., El secuestro de la Justicia, Madrid, 1997, en págs. 410 y ss., hacen referencia a muchos de los que ingresaron por el tercer o cuarto turno que tenían relación con los partidos políticos o con algunos de sus miembros.

${ }^{8}$ Es frecuente que ante presuntos supuestos de corrupción, que tal vez puedan ser constitutivos de delito, se denieguen comisiones para investigarlos en las Comunidades Autónomas. En Andalucía por ejemplo, se han denegado todas las peticiones solicitadas por la oposición, que superan las setenta. También ha ocurrido en otras comunidades, incluso en el Parlamento. 
riesgo de posibles intervenciones telefónicas ha llevado a que los abogados traten personalmente con sus clientes cuestiones que puedan comprometerles y no a través del teléfono. Se ha llegado a violar, por la autoridad judicial, derechos fundamentales como la intervención de conversaciones entre abogados y sus defendidos celebradas en prisión, lo que sólo está permitido para casos de terrorismo9 ${ }^{9}$ En diversos sectores de la población hay personas que toman precauciones en sus conversaciones telefónicas ante el temor de que su teléfono o el de la otra persona esté intervenido. También los sistemas electrónicos son objeto de preocupación ${ }^{10}$.

Si se llega a esa descentralización judicial, por cuestiones políticas, poder económico u otro tipo de influencias, habrá autores de delitos a los que no se les perseguirá; hoy ya ocurre. Cuando no haya más remedio que hacerlo se procurará imponer una pena menor de la que realmente correspondería; también cabe la posibilidad de perseguir a inocentes utilizando pruebas o testigos falsos. Existe el riesgo de intentar utilizar a la policía con fines torticeros, a lo que ésta se debe negar. Con el control de las prisiones se puede jugar a favor o en contra de lo que convenga (ingresar o no, estar poco tiempo privado de libertad, disfrutar de permisos u otras prebendas como pueden ser los beneficios penitenciarios irregulares). El panorama puede termi-

9 Dispone el art. 51.2 de la Ley General Penitenciaria de 1979: «Las comunicaciones de los internos con el Abogado defensor o con el Abogado expresamente llamado en relación con asuntos penales y con los Procuradores que los representen, se celebrarán en departamentos apropiados y no podrán ser suspendidas o intervenidas salvo por orden de la autoridad judicial y en lo supuestos de terrorismo». Vid. prensa nacional de los días 9-10-2009 y siguientes.

10 BALLESTEROS, R.P en La Gaceta, de 11 de septiembre de 2009, pág. 10, en un artículo titulado "Los internautas denuncian ante la UE el "software espía" recoge: "La Asociación de Internautas denunció a finales de julio ante la Comisión Europea que el Sistema Integral de Interceptación de Comunicaciones Electrónicas (Sitel) permite acceder a una serie de datos personales tan sensibles como la identidad, el DNI o los lugares por los que ha pasado una persona y con quién ha hablado en el último año. Esta información, asegura la denuncia, está disponible para los agentes de la Policía. Y, además, según la Ley 25/2007, los funcionarios facultados pueden acceder a estos datos sin necesidad de obtener una orden judicial, algo que sólo es obligatorio para pinchar una llamada; es decir, para escuchar el contenido de la conversación». En La Gaceta del día 24, pág. 21, escribe: «Ayer, la Asociación de Internautas solicitó al Defensor del Pueblo, Enrique Múgica, que ponga en marcha una investigación sobre cómo funciona la aplicación informática que utilizan las fuerzas de seguridad y el Centro Nacional de Inteligencia para interceptar llamadas telefónicas».

Ley 25/2007, de 18 de oct. de conversación de datos relativos a las comunicaciones electrónicas y a las redes públicas de comunicaciones (BOE n. ${ }^{\circ} 251$ del 19), modifica la Ley 32/2003 General de Comunicaciones, art. 33 (secreto de las comunicaciones. Vid actual redacción del art. 33.6 y 8) y arts. 38, 53 y 54 . 
nar siendo desolador, pues los caciques de hoy pueden mañana convertirse en caudillos.

Politización de la Justicia. Se insiste de nuevo sobre esta cuestión, pues supone un grave riesgo para la seguridad jurídica y la democracia. A esto han contribuido tanto los socialistas como los populares, y también los nacionalistas. El asalto a la Justicia se inicia en el año 1985, con la Ley Orgánica del Poder Judicial que en su artículo 112 establecía que la propuesta para el nombramiento de los 20 vocales del Consejo General del Poder Judicial era competencia de los partidos políticos (Congreso y Senado) ${ }^{11}$. El artículo 122.3 de la Constitución no establece quien ha de proponer a los doce consejeros que han de nombrarse entre jueces y magistrados, aunque dice que se hará «en los términos que establezca la ley orgánica» ${ }^{12}$. Al no hacer referencia, como ocurre en el inciso segundo, de que la propuesta de los otros ocho consejeros se hará: «cuatro a propuesta del Congreso de los Diputados y cuatro a propuesta del Senado», debió de entenderse que para los doce jueces y magistrados había que seguir otro sistema, como así lo recogía el Proyecto de Ley Orgánica del Poder Judicial de $1984^{13}$.

La Ley fue recurrida ante el Tribunal Constitucional por considerarse que el artículo 112 de la LOPJ era inconstitucional. El Tribunal,

11 La Ley Orgánica 6/1985, de 1 de julio, del Poder Judicial en su redacción inicial dispuso en su artículo 112: «1. Los Vocales del Consejo General del Poder Judicial serán propuestos por el Congreso de los Diputados y por el Senado ...».

${ }_{12} \mathrm{El}$ art. 122.3 de la Constitución recoge: «El Consejo General del Poder Judicial estará integrado por el Presidente del Tribunal Supremo, que lo presidirá, y por veinte miembros nombrados por el Rey por un período de cinco años. De éstos, doce entre Jueces y Magistrados de todas las categorías judiciales, en los términos que establezca la ley orgánica; cuatro a propuesta del Congreso de los Diputados y cuatro a propuesta del Senado, elegidos en ambos casos por mayoría de tres quintos de sus miembros, entre abogados y otros juristas, todos ellos de reconocida competencia y con más de quince años de ejercicio en su profesión».

13 En el BOCG, Congreso de los Diputados, Serie A, núm. 118/I de 19 de septiembre de 1984, se publica el Proyecto de Ley del Poder Judicial (Orgánica), su artículo 124 viene a coincidir con el 122.3 de la Constitución, sustituyendo «miembros», por «vocales», y desapareciendo la referencia: «en los términos que establezca la ley orgánica», quedando el inciso primero del art. 124 del Proyecto como sigue: «El Consejo General del Poder Judicial estará integrado ... De éstos, doce entre Jueces y Magistrado de todas las categorías judiciales, cuatro a propuesta del Congreso de los Diputados y cuatro a propuesta del Senado ...». Por su parte el art. 125 del Proyecto establecía: "Los doce Vocales de procedencia judicial serán elegidos entre Jueces y Magistrados pertenecientes a todas las categorías judiciales, de conformidad con el procedimiento regulado en los artículo 126 y siguientes de esta Ley», no interviniendo para nada ni el Congreso ni el Senado. 
en sentencia 108/1986, de 29 de julio, confirmó, como era previsible, el sistema establecido en la LOPJ. No obstante, ya apuntaba del riesgo de politización de la Justicia ${ }^{14}$. El partido de la oposición en reiteradas ocasiones dijo que si llegaba al poder cambiaría el sistema con respecto a la propuesta de elección de los doce vocales entre jueces y magistrados. Los populares teniendo mayoría absoluta en el Gobierno pudieron hacer el cambio prometido. Sin embargo no lo hicieron, pues también querían influir en la Justicia ${ }^{15}$. Para justificar que cumplían lo anunciado, en el año 2001 se modificó el art. 112 de la LOPJ, que no resolvía nada, pues la propuesta de nombramiento de todos los Consejeros sigue haciéndose por el Congreso y el Senado.

En relación con el Consejo General del Poder Judicial, la politización cabe deducirse de la lucha de los dos partidos mayoritarios - sin olvidar los nacionalistas - para consensuar la propuesta de nombramiento de los Consejeros ${ }^{16}$. Para un 85 por ciento de los abogados «la politización del CGPJ es tan elevada que impide gestionar de forma eficiente e imparcial el funcionamiento de la Justicia» ${ }^{17}$. Si ello es así, el Consejo General no está en condiciones para cumplir parte de las atribuciones que se recogen en el título II, del libro I, de la LOPJ, especialmente la propuesta de ciertos nombramientos.

La cuestión es realmente importante si se tiene en cuenta que dentro de las funciones que le atribuye la LOPJ está la de hacer propuestas de nombramientos en los órganos más relevantes de la Administración

${ }^{14} \mathrm{Vid}$. inciso final del párrafo segundo de su FJ 13, y párrafo último del mismo de la sent. 108/1986.

15 NIETO, A., El desgobierno judicial, Madrid, 2004, en pág. 248 escribe: «La politización partidista (y no democrática) de los jueces iniciada por el partido socialista fue asumida por el partido de la oposición cuando llegó al gobierno y se percató de las ventajas de tener sometido al Poder Judicial».

${ }_{16}$ NIETO, en El desgobierno de lo público, cit., pág. 321 recoge: «En cualquier caso 2007 ha sido devastador para la Administración de Justicia y hasta para la imagen de ella. Porque es el caso que los vocales del CGPJ no se han puesto de acuerdo en los cupos que corresponden a cada partido y en consecuencia no se ha procedido a una renovación que se ha retrasado más de un año. Los partidos saben que se juegan mucho en la composición del Consejo —nada menos que la previsión de los altos cargos de la Magistratura - y no ceden aunque sea a costa de un escándalo sin precedentes, que tiene, no obstante, su lado bueno, a saber: que hasta los ciegos y sordos han llegado a comprender, en fin, que los jueces no son neutrales, sino que deciden como marionetas de los partidos políticos que los manejan desde detrás».

17 Datos tomados de una encuesta de Metroscopia a 5.243 abogados encargada por el Consejo General de la Abogacía. Los resultados se publican en la Revista General de la Abogacía española. Abogados, núm. 56/2009. El Presidente de la Abogacía añade que todos los Consejos, hasta el actual «han estado fuertemente politizados, y los vocales han actuado siguiendo criterios partidistas». 
de Justicia ${ }^{18}$, lo que a la postre puede influir en resoluciones relacionadas con la lucha de los partidos políticos o de particulares. Habría que dejar en suspenso esta función, hasta que se encuentre una fórmula más adecuada, como puede ser por el sistema de antigüedad.

Teniendo en cuenta su composición, y el interés de los partidos políticos por influir en la Justicia, su credibilidad es prácticamente nula, como hemos visto que opinan los abogados. También los ciudadano se inclinan por la politización ${ }^{19}$. Algún autor llega a decir que la voluntad de sus componentes es ciega y servil ${ }^{20}$. Así las cosas más de uno se preguntará ¿cómo es posible que puedan existir profesionales del Derecho, que a pesar de tener resuelta su vida se prestan a formar parte de dicho Consejo?, pues los hay. La propuesta de nombramiento debía de hacerse por sorteo entre los aspirantes que reunieran una serie de méritos profesionales.

El Consejo no debería intervenir en la propuesta de ningún nombramiento, y para evitar los posibles efectos políticos ${ }^{21}$ todo tendría que

18 Según el art. 127 de la LOPJ es competencia del Pleno del Consejo del Poder Judicial «1. La propuesta de nombramiento por mayoría de tres quintos de sus miembros de: a) El Presidente del Tribunal Supremo y del Consejo General del Poder Judicial y el Vicepresidente de este último. b) Los miembros del Tribunal Constitucional cuya designación le corresponde. c) Los Presidentes de Sala y Magistrados del Tribunal Supremo, así como los Presidentes de los Tribunales Superiores de Justicia de las Comunidades Autónomas [...] 3. Evacuar la audiencia prevista en el artículo 124.4 de la Constitución sobre nombramiento del Fiscal General del Estado». Según el art. 124.4 de la Constitución: «El Fiscal General del Estado será nombrado por el Rey, a propuesta del Gobierno, oído el Consejo General del Poder Judicial».

${ }_{19}$ El diario El Mundo de 22 agosto 2008 en pág. 24 publica una encuesta que encarga a Sigma Dos sobre la opinión que los ciudadanos tienen sobre la Administración de Justicia. A la pregunta ¿qué prefiere usted, que todos los miembros del Consejo General del Poder Judicial sean elegidos por ...?, Parlamento y jueces $(59,8 \%)$, por los jueces (16,3\%), el Parlamento (14,2\%), Ns/Nc (9,7\%).

${ }_{20}$ NIETO, en El desgobierno de lo público, cit., pág. 322, escribe: «En el ámbito político el CGPJ se ha convertido en un instrumento del Poder, cuya voluntad ejecuta de manera ciega y servil. El Consejo General es un mandatario de los partidos políticos que actúan sobre él sin el menor escrúpulo y en la medida que ha desmantelado su independencia, es el autor material de la desaparición real del llamado Poder Judicial».

${ }^{21}$ NIETO, ob. y pág. cit., continúa diciendo: «El Gobierno [...] lo único que tiene que hacer es ocupar el CGPJ con personas de su total confianza política y luego dejar que éstas realicen por sí mismos todo el trabajo sucio. El CGPJ realiza de hecho los nombramientos de los cargos decisivos de la Alta Magistratura, que naturalmente recaen en personas de confianza del partido que ha nombrado a los vocales del Consejo [...] Cumplidos sus objetivos, los partidos y el CGPJ se retiran solemnemente de la arena política y se convierten en hipócritas espectadores neutrales que respetan de manera escrupulosa la "independencia judicial". El trabajo sectario viene luego, en la lucha cotidiana de los procesos políticamente delicados, en sus deliberaciones y votos, donde cada uno defiende los intereses de sus mandantes sin que sea preciso recor- 
hacerse en base a la antigüedad. No hay que fiarse de que en la elección se proponga o se nombre al más capacitado, y no al más obediente, el más politizado, o al que simplemente tiene mayor número de apoyos. Hay que tener en cuenta que un ascenso, o el desempeño de un cargo de relevancia lleva consigo muchas prebendas. Quien ocupe un puesto en base a la antigüedad tiene la ventaja de no debérselo a nadie, y por tanto puede ser independiente, pudiendo eludir las presiones políticas mejor que quien ha sido nombrado por su afinidad o simpatía a un partido político. El sistema de antigüedad también evitaría que los «trepas» se prestaran a hacer cosas que no debieran con el propósito de conseguir un ascenso. Tampoco el Consejo debe intervenir en materia disciplinaria ${ }^{22}$, pues existe el riesgo de que no se inicien expedientes cuando hay motivo para ello, o que las sanciones no sean las adecuadas. Esto ocurre también en la Administración en general, ya que los encargados de inspecciones normalmente son funcionarios del mismo cuerpo, por lo que la tendencia es a minimizar las infracciones. Habría que modificar el sistema.

La falta de seriedad en la propuesta de los Consejeros se pone de manifiesto en el hecho de que un delincuente haya podido llegar a formar parte del mismo ${ }^{23}$. Por tanto, si de 20 Consejeros uno lo era, el Consejo daba una tasa de delincuencia superior a la media nacional, pues en España no hay un condenado por cada 20 habitantes.

Las Salas de lo Civil y Penal de los Tribunales Superiores de Justicia tampoco escapan del riesgo de estar politizados ya que en el

datorio alguno. En la pelea se embarran inevitablemente las togas, pero esto ya se sabía de antemano al aceptar el nombramiento. Una peculiaridad interesante del sistema actual es, en fin, la inevitable formación de dos grupos enfrentados de "jueces fieles", de servidores militantes de los dos partidos que se van alternando en el poder».

${ }^{22}$ NIETO, en El desgobierno de lo público, cit., pág. 324 escribe: «En ciento cincuenta años se ha condenado penalmente a cinco jueces de carrera, y disciplinariamente, desde que se estableció el CGPJ hace treinta años, se han impuesto sanciones graves a media docena, no puede afirmarse seriamente que el sistema represivo funciona».

${ }^{23}$ DÍAZ HERRERA e Isabel DURÁN, en ob. cit., pág. 337 dicen: Un «abogado mercantilista catalán, Pascual Estevill accede a la magistratura, por el cuarto turno, el 7 de junio de 1990. Cuatro años y unos meses más tarde, el 3 de noviembre de 1994, Convergència i Unió lo promociona al Consejo General del Poder Judicial, donde permanece hasta abril de 1996». REQUERO, en ob. cit., pág. 77, escribe: "¿Acaso no fue una ofensa a la Justicia que CiU enviase al tercer Consejo a un delincuente (Pascual Estevill)?, ¿acaso no lo fue que al quinto enviase a un notario sancionado por sus irregularidades profesionales y que se comprometió ante el Congreso de los Diputados a dimitir si era castigado? Esto es lo que el nacionalismo catalán entiende que se merece el Poder Judicial español». Estevill fue condenado a una severa pena de prisión por varios delitos en sentencia de 3 de enero de 2005, confirmada por el Tribunal Supremo. 
nombramiento de alguno de los magistrados interviene el Consejo General del Poder Judicial y la asamblea legislativa de la Comuni$\mathrm{dad}^{24}$. A la Sala de lo Penal le corresponde, entre otras funciones, «el conocimiento de las causas penales que los Estatutos de Autonomía reservan al conocimiento de los Tribunales Superiores de Justicia...», sus competencias se extienden a materias relacionadas con el personal aforado de las autonomías. Puede suceder, y sucede, que algún magistrado tenga afinidad con el partido político del encausado o con el contrario, lo que puede poner en duda su imparcialidad. La realidad es que se han nombrado magistrados con marcada afinidad política que ni siquiera pertenecían a la carrera judicial ${ }^{25}$.

Con respecto a la politización del Tribunal Constitucional, hay que tener en cuenta que son los partidos políticos, el Gobierno y el Consejo General del Poder Judicial los que proponen el nombramiento de los 12 miembros del Tribunal Constitucional ${ }^{26}$. Con respecto a este Tribunal hay quien dice que lo importante no es saber, sino saber votar y que se utiliza para justificar decisiones políticas ${ }^{27}$, o que se ha

${ }^{24}$ Dispone el art. 330.4 de la LOPJ: «En las Salas de lo Civil y Penal de los Tribunales Superiores de Justicia, una de cada tres plazas se cubrirá por un jurista de reconocido prestigio con más de 10 años de ejercicio profesional en la comunidad autónoma, nombrado a propuesta del Consejo General del Poder Judicial sobre una terna presentada por la Asamblea legislativa».

25 REQUERO, en ob. cit., pág. 39 escribe: La LOPJ «al crear en las comunidades autónomas las salas de lo civil y penal de los tribunales superiores de Justicia, ideó un mecanismo de alta politización judicial [...] Parte de sus magistrados no son de carrera, sino propuestos por los propios grupos políticos de cada asamblea autonómica [...] Desde 1985 hemos visto cómo por esta vía son hechos magistrados ex gobernados civiles, ex diputados, ex parlamentarios, ex presidentes de asambleas o, en definitiva, personas de confianza de los partidos. En resumen, se trata de órganos judiciales que forman parte del reparto del botín electoral».

26 Dispone el art. 159.1 de la Constitución: «El Tribunal Constitucional se compone de 12 miembros nombrados por el Rey; de ellos, cuatro a propuesta del Congreso por mayoría de tres quintos de sus miembros; cuatro a propuesta del Senado, con idéntica mayoría; dos a propuesta del Gobierno, y dos a propuesta del Consejo General del Poder Judicial». Art. 160:«El presidente del Tribunal Constitucional será nombrado entre sus miembros por el Rey, a propuesta del mismo Tribunal en pleno y por un período de tres años».

27 REQUERO, J.L., El asalto a la Justicia. La última barrera ante el totalitarismo, Madrid, 2009, en pág. 124 escribe: «Hace tiempo me decía un magistrado del Tribunal Supremo que lo determinante de un miembro del Tribunal Constitucional no es que sepa Derecho, sino que sepa votar. Me escandalizó [...] Pero cuando los partidos hablan de los magistrados del Constitucional como peoncillos en el ajedrez de su lucha, se llega a la conclusión de que, en efecto, lo que vale no es su capacidad ni su sabiduría jurídica, sino que sepan qué tienen que votar. Este tribunal se convierte en la gran coartada para justificar con lenguaje y formas jurídicas las decisiones políticas». 
convertido en un nuevo frente de lucha política ${ }^{28}$, los ciudadanos se inclinan por su politización ${ }^{29}$. Teniendo en cuenta las críticas de que han sido objeto algunas de sus decisiones ${ }^{30}$, y a fin de evitar toda posible sospecha sobre su politización o imparcialidad, considero que la propuesta para el nombramiento de los magistrados debía de hacerse por sorteo entre todos los que, reuniendo una serie de requisitos, optaran por formar parte del mismo. De este modo se evitaría toda duda sobre su imparcialidad, sin perjuicio de que más tarde alguno se dejara influir.

Dentro de la judicatura y la fiscalía existen diversas asociaciones que buscan los puestos de poder de los que no escapa la influencia política. En realidad es un quítate tú para ponerme yo. La politización de algunos jueces, fiscales ${ }^{31}$ y policías ${ }^{32}$ supone un grave riesgo para la consolidación de cualquier sistema democrático. Esto junto

${ }^{28}$ NIETO, El desgobierno de lo público, cit., en pág. 331 escribe: «Todo vale, pues, para "colocar" un magistrado favorable dado que las sentencias ya no se hacen por reflexiones jurídicas, sino por instrucciones del partido. El Tribunal Constitucional se ha convertido ni más ni menos que en un nuevo frente de la lucha política, como las Cortes o las campañas electorales».

${ }^{29}$ Encuesta El Mundo-Sigma Dos, cit. A la pregunta «El Tribunal Constitucional le parece un órgano ....»: politizado $(71,2 \%)$, imparcial y despolitizado $(17,6 \%)$, Ns/Nc $(11,2 \%)$.

${ }^{30}$ Se ha criticado al TC por el retraso que está sufriendo la sentencia que ha de dictar sobre los siete recursos de inconstitucionalidad interpuestos contra el Estatuto de Cataluña, que entró en vigor en agosto de 2006. Transcurridos tres años se han dictado por la Generalitat de Cataluña más de 30 leyes sobre diversas cuestiones. Ha habido ataques al Tribunal respecto de la resolución que pudiera tomar en su sentencia, en cuanto modificara su contenido, que posiblemente en algún caso podíamos estar ante un delito de amenazas del art. 504.1 del Código penal, o atentado contra la independencia judical del art. 508.2.

31 GÓMEZ DE LIAÑO, J., en el diario El Mundo de 18 de septiembre de 2009, pág. 21, en su artículo ¿Hasta cuándo, señor fiscal? dice «que el Ministerio Fiscal lleva años sumido en un bache de desprestigio ... la culpa sin duda es de quienes tercamente están empeñados en barrer todo lo que signifique independencia para la Justicia». El diario $A B C$ de 9 de febrero de 2009 en su pág. 21 hace referencia a la protesta de los fiscales conservadores en cuanto denuncian una purga ideológica del fiscal general del Estado en la Comunidad Valenciana. Esto es un ejemplo sobre la politización de la Fiscalía. La prensa pone en duda la imparcialidad de la Fiscalía en algunos casos, vid. por ejemplo el diario El Mundo de 2-2, 4-10, 6-10 y 11-10-2009.

${ }^{32}$ FUENTES, J.A., Presidente del Sindicato Profesional de Policía, en Revista Época, núm. 1255, julio 2009, págs. 19 y ss., dice que el Ministro del Interior «ha puesto a su servicio a la Policía ... entre los altos mandos o Escala Superior del Cuerpo Nacional de Policía, el 100\% son de libre designación ... son una herramienta muy útil para controlar a los funcionarios y ponerlos a su servicio». A la pregunta ¿Se había dado antes un grado de politización semejante con Ministros anteriores? Contesta: «Nunca ... Todos los Ministros del Interior tienen tendencia a controlar, es algo innato al cargo y a la política pero ni los mayores del lugar recuerdan nada parecido. Ahora, quienes dirigen la Policía no son los mejores». 
con la alta corrupción que existe en nuestro país ${ }^{33}$ a nivel general, y en mayor proporción en la clase política ${ }^{34}$, no permite que tengamos un sistema democrático aceptable que seguirá deteriorándose. La obediencia al poder político ${ }^{35}$ de unos pocos, normalmente dispuestos a cometer cualquier tropelía, a favor de unos y en perjuicio de otros, desprestigia la institución a la que pertenecen, donde la mayoría de sus componentes son honestos y no se prestan a la corrupción. Denunciar cualquier irregularidad tiene su riesgo ${ }^{36}$. De ahí la importancia que tiene para el poder la elección arbitraria de mandos dóciles, que normalmente no son los más capacitados. Los puestos de libre designación se han convertido en una corruptela nacional, tanto a nivel central como autonómico; además de no nombrar a los mejores, con lo que pueden cometerse delitos de prevaricación, se politizan los organismos, creando tensiones en el personal que repercuten negativamente en su rendimiento.

Hay casos flagrantes de abusos por parte de algunos jueces al considerarse seguros de su impunidad ${ }^{37}$. El poder que tienen en España, y en general en casi todos los países, es inmenso. A veces ese poder se ejerce con abusos. Han de tener en cuenta que desempeñan una labor muy delicada, y que sus errores pueden tener graves consecuencias, así como los excesos; de ahí que han de ser escrupulosos en su función, interpretando la ley de la forma que estimen más correcta y no en el sentido de favorecer o perjudicar a alguien. No son pocos los que consideran que están por encima de lo divino y de lo

${ }^{33}$ El diario El Mundo, de 28 de agosto de 2008, pág. 12, publica una encuesta encargada a Sigma Dos sobre la corrupción en España. A la pregunta ¿En cuál de estos sectores cree que hay más corrupción?: La política $(62,9 \%)$, justicia $(14,4 \%)$, medios de comunicaciones $(9,1 \%)$.

${ }^{34}$ CERVANTES, en El coloquio de los perros, escribe: «quede suspenso cuando vi que los pastores eran los lobos».

35 En el diario El Mundo, en la encuesta de Sigma Dos cit, recoge: a la pregunta ¿cree que los gobiernos utilizan su poder en los órganos judiciales para controlar las decisiones de los jueces?, responden: si $(70 \%)$, no $(19,9 \%)$, Ns/Nc $(10,1 \%)$.

36 GARCÍA ABADILLO, C., en El Mundo, de 22 de junio 2009, portada, bajo el título «Saiz somete a 10 agentes del CNI a la máquina de la verdad» escribe: «La semana pasada, tras la publicación por El Mundo de las denuncias hechas por determinados agentes y mandos del CNI sobre las irregularidades cometidas por su director, Saiz, el responsable de seguridad del Centro tomó una iniciativa sin precedentes: ordenó la aplicación de la prueba del polígrafo, también conocido como de la máquina de la verdad, a una decena de agentes sospechosos de haber filtrado información. Al menos tres de los citados se negaron a pasar por dicha prueba, tras consultar con los servicios jurídicos del Centro». La denuncia era por el uso de medios públicos para fines privados.

37 Vid supra nota 22. 
humano, y en ese sentido actúan, sin riesgo por sus arbitrariedades. En todo caso hay que aclarar que la mayoría de los jueces cumplen correctamente con su función, son independientes y no quieren saber nada de la política ${ }^{38}$. No obstante, corren el riesgo de ser presionados, lo que les pondrá en situaciones embarazosas a las que han de resistir, ya que la Justicia es la última trinchera para defender la democracia. No todos pueden soportar las fuertes presiones a las que se ven sometidos.

Es preferible sufrir la agresión de un delincuente que estar sometido a un procedimiento judicial siendo inocente. Una cuestión muy debatida, que conlleva graves consecuencias para muchos ciudadanos, es la denominada imputación por la presunta comisión de un delito, que puede llegar hasta la pena de banquillo — sufrir el juicio oral- Es normal que cuando se interpone una denuncia o querella contra un ciudadano, por hechos que pueden ser ciertos o no, el juez competente le llame a declarar como imputado sólo en base a lo que se dice en el escrito. Hay que tener en cuenta que la imputación teóricamente supone que hay algún indicio contra él, aunque sea mínimo, de haber cometido el delito del que le acusa el denunciante o querellante. El juez normalmente no suele hacer una investigación previa suficiente para determinar si hay razones fundadas para decretar la imputación; el argumento absurdo que se utiliza es que compareciendo como imputado se tienen más garantías, pues además de ir acompañado de abogado, no está obligado a decir la verdad de lo que se le pregunte, puede negarse a declarar o incluso mentir ${ }^{39}$. A quien nada tiene que ocultar y nada de que responder por ser inocente, no se le puede decir que se le concede la gracia de que puede negarse a declarar o mentir, pues lo que quiere es contar la verdad. Hay que indicar que una imputación injustificada puede dar lugar a un delito de prevaricación dolosa o por im-

38 NIETO, El desgobierno judicial, cit., en pág. 248 escribe: «Cierto es, desde luego, que los partidos no cuentan con todos los jueces, puesto que la mayoría de ellos sigue creyendo que la política debe ser ajena a la función jurisdiccional y que con la toga puesta basta con ser sinceramente constitucional; pero el hecho es que para manipular el Poder Judicial no se precisa más que un puñado de jueces de confianza, y éstos los tienen tanto los partidos de ámbito nacional como los nacionalistas».

39 Entiendo que lo correcto, y para evitar los problemas que lleva consigo la condición de imputado, sería dar traslado por el instructor de copia de la denuncia o querella a la persona a quien se acusa de la comisión de un delito, a fin de que ésta pueda hacer los descargos que considere oportunos. Será más tarde, si hay motivos suficientes, cuando debe admitirse a trámite la denuncia o querella y decretar la imputación. Vid. SERRANO GÓMEZ, A., «La condición de imputado en el proceso penal», en La Ley, núm. 4.843, de 20 de julio de 1999. 
prudencia ${ }^{40}$. Los abogados, en la presentación de una querella han de ser muy escrupulosos. No se debe acusar a nadie sin pruebas sólidas, ya que se puede cometer un delito de denuncia falsa ${ }^{41}$, en el que también puede incurrir la Policía en sus atestados ${ }^{42}$ y el propio Ministerio Fiscal si son falsos los hechos que imputan ${ }^{43}$.

La imputación tiene consecuencias personales y sociales normalmente estigmatizantes ${ }^{44}$ que a veces son muy graves; incluso algunos pierden su puesto de trabajo, su prestigio social, y no pocos terminan en tratamiento psiquiátrico o psicológico. En ocasiones el origen de todo ello puede tener un trasfondo político, lo que complica todavía más la situación de los imputados ${ }^{45}$. La prensa y otros medios de

40 Puede ocurrir este tipo de imprudencia por admitir con ligereza una denuncia o querella a trámite - puede ser el mero hecho de no haberla leído-, decretar la imputación de las personas denunciadas o querelladas, y esperar a ver lo que sucede tras la declaración de los imputados, ratificación de la querella, etc. En principio estamos ante un claro supuesto de negligencia; si con posterioridad resulta claramente que no existían indicios suficientes para su admisión a trámite, decretándose más tarde el archivo, podemos estar ante una prevaricación por imprudencia grave (art. 447 del Código penal). Pero que nadie espere que por esto se pida algún tipo de responsabilidad a ningún juez.

${ }^{41}$ No se puede utilizar a la Administración de Justicia para coaccionar a los querellados buscando pactos torticeros, injustos o que tienen su solución en otra vía legal ajena a la penal.

${ }^{42}$ Vid. MAQUEDA ABREU, M. ${ }^{a}$ L., Acusación y denuncias falsas, Valencia, 1999, págs. 29 y ss.

${ }^{43}$ Vid. VERGER GRAU, J., La defensa del imputado y el principio acusatorio, Barcelona, 1994, pág. 50.

${ }^{44}$ Con referencia a la estigmatización, dispone el auto de la Sala Segunda del Tribunal Supremo de 14 de noviembre de 1996 en la causa especial 2530/1995, donde se debatió este problema respecto de algún político. Del mismo cabe destacar: a) «... La condición de imputado en un proceso penal no conlleva únicamente ventajas, sino también una serie de cargas o efectos negativos, tanto procesales como extraprocesales ...». b) «En segundo lugar ... tanto en el proceso ordinario como en el abreviado, la citación como imputado - aun cuando se acuerde formalmente "para ser oído»constituye al así citado en parte material del proceso, con facultades plenas para intervenir y ejercitar el derecho de defensa, y también con las subsiguientes cargas o efectos negativos. Incluso cabe afirmar que el efecto estigmatizador de la imputación judicial es generalmente superior en las causas que se tramitan por el procedimiento ordinario dada la mayor gravedad de los delitos objeto de imputación». En el antiguo procedimiento de urgencia se utilizaba el término "encartado».

45 La Memoria de la Fiscalía General del Estado de 2005, pág. 480, hace referencia a la bajeza moral a la que llegan algunos denunciando a sus adversarios políticos en busca de algún beneficio. "Para evitarlo es preciso que la Fiscalía agote las vías de investigación para decidir si realmente existen o no indicios suficientes que justifiquen la incoación del correspondiente procedimiento judicial».

BURGO, J.I. (del), El escándalo del lino. Historia de una infamia, Madrid, 2009, relata un procedimiento que se inicia próximo a unas elecciones autonómicas en 1999. 
comunicación suelen airear los asuntos de mayor trascendencia ${ }^{46}$, lo que perjudica más a los imputados. La propia Memoria de la Fiscalía General del Estado se hace eco de los problemas que se crean con la imputación ${ }^{47}$. Como el injustamente imputado no ha hecho nada al final se archiva su procedimiento, o tras sufrir el juicio correspondiente se le absuelve. Ni siquiera se le piden disculpas al ofendido, quien, además, parece que ha de quedar agradecido de que no se le condene; ello sin olvidar los gastos que le ha supuesto el procedimiento. Los problemas que crea la imputación a veces duran muchos años, incluso toda la vida; hay que tener en cuenta que algunas sentencias pueden tardar en dictarse hasta quince años ${ }^{48}$, aunque esto sea excepcional. Por el contrario, si te ataca un delincuente, te despojará de tus bienes, de lo que es posible recuperarse; te podrá causar unas lesiones que si no son mortales sanarán, pero las consecuencias posiblemente sean menores que las soportadas en la condición de imputado. Si eres agredido por un delincuente tienes la opción de contarlo a tus más allegados, pero si has sido injustamente imputado lo normal es que ocultes esta situación, pues por muy clara que sea tu inocencia algunos pensarán: «algo habrá hecho».

Se imputaron 42 personas, entre ellas una ministra y otros cargos políticos; también fueron involucradas 18 personas jurídicas. Todos resultaron absueltos en sentencia dictada por la Audiencia Nacional en octubre de 2006 y confirmada por el Tribunal Supremo en mayo de 2008. Bruselas puso una multa al gobierno español de 126 millones de euros. Termina la obra recogiendo en la cubierta: «Es ésta la historia de una infamia. En ella se muestra hasta qué punto políticos sin escrúpulos pueden destruir la reputación de personas inocentes con el fin de obtener réditos electorales y prueba cómo la Justicia se convierte en un instrumento diabólico si se ejerce por jueces y fiscales carentes de imparcialidad».

46 En no pocas ocasiones los medios de comunicación dan publicidad a los hechos por los que se imputa a alguna persona y que conocen antes que éste. Los imputados muchas veces se enteran de su situación por los indicados medios. Es frecuente que revelen cuestiones relacionadas con el procedimiento, incluso habiéndose decretado el secreto de las actuaciones. Nunca se investigan estas filtraciones, pese al perjuicio que muchas veces se ocasiona a personas que incluso son inocentes.

47 La Memoria de la Fiscalía General de Estado de 1997, en su pág. 636 recoge: «No se puede dejar de lado que en la sociedad actual la relevancia de los medios de comunicación y la forma en la que presentan las noticias referidas a determinados temas de interés (o que los propios medios convierten en tema de interés), hace que la comparecencia ante un Juzgado en calidad de imputado, aunque no lleve aparejada la adopción de medida cautelar alguna, suponga para el compareciente una fuerte dosis de negatividad en el concepto público, lo cual, según las personas y los asuntos, pueden tener enorme trascendencia. De esta forma, la regulación legal se hace acreedora a la crítica, pues una decisión con las consecuencias que produce, intra y extra procesales, debería estar mejor regulada y, en cualquier caso, ir acompañada de una suficiente motivación».

48 Vid. infra nota 55. 
Así como se habla del virus de los hospitales, donde el más sano puede coger una enfermedad, también existe un virus judicial. Se puede imputar a una persona inocente y durante el procedimiento complicarse las cosas en su contra, como puede ser la declaración de un testigo falso, o la interpretación torticera que se haga de la declaración de un testigo que incluso puede actuar de buena fe, o por otras muchas circunstancias. Al final, aunque es difícil, el inocente puede ser condenado. El estar incurso en un procedimiento, aunque sea de testigo, resulta muy molesto, por lo que nadie quiere colaborar con la Justicia, porque en la situación actual se la teme, se desconfía de su protección. La Administración de Justicia está ocasionando graves perjuicios a muchos ciudadanos inocentes. Hoy puede utilizarse para crear problemas a alguien, o vengarte de un enemigo. Se presenta contra él una denuncia o querella por hechos falsos, y se consigue que se decrete su imputación -lo que no es difícil-, después se da a conocer en su entorno, y para conseguir mayor efecto, se acude a los medios de comunicación. Cuando todo se aclare, si se aclara, es probable que al falso denunciante no se le aplique ningún tipo de sanción. El perjudicado podrá iniciar un procedimiento contra aquél, que muchas veces no se hace por el coste económico que supone, estar harto de la Justicia y desconfiar de que finalmente su acción tenga éxito. También a veces se utiliza la Justicia para intentar perjudicar al contrincante político ${ }^{49}$, lo que cada vez es más frecuente.

Con el paso del tiempo la sociedad ha ido perdiendo confianza en la Administración de Justicia. Se ha pasado de respetarla a temerla. Muchos de los ciudadanos que acuden a ella desconfían de la misma, por la inseguridad en el resultado. Lo más grave es cuando existe motivación política. La balanza de la Justicia no está siempre horizontal, pues con bastante frecuencia aparece desequilibrada; de todas formas, la Administración de Justicia es algo tan complejo que por mucho interés que ponga el juzgador no siempre podrá llegar a una solución totalmente justa. No obstante, se han desbordado las reglas tradicionales de la interpretación del Derecho, encontrándonos a veces con resoluciones interesadas, retorcidas e incomprensibles. Por ejemplo, en la forma de interpretar la prescripción del delito, lo que ha llevado últimamente al enfrentamiento entre el Tribunal Constitucional y el Tribunal Supremo - cuestión todavía sin resolver-, la postura de éste ha evolucionado hasta llegar a mantener trece criterios distintos ${ }^{50}$, incluso en contra de la línea mantenida por la doc-

49 Vid. supra nota 45.

50 Vid. SERRANO GÓMEZ, A., La prescripción del delito (tres cuestiones), Madrid, 2003, págs. 44 y ss. 
trina mayoritaria. La polémica sigue latente y el legislador no se atreve a resolverla; busca una solución salomónica con respecto a la postura mantenida por ambos tribunales, lo que ni es de recibo ni termina con el problema ${ }^{51}$. Al legislador habría que recordarle el consejo que don Quijote da a Sancho, gobernador de la ínsula Barataria: «No hagas muchas pragmáticas y si las hicieres procura que sean buenas ${ }^{52}$. Un eminente magistrado escribe sobre diversos tipos de sentencias ${ }^{53}$, entre las que cabe destacar aquella a la que califica $a$ gusto del chef ${ }^{54}$; otro magistrado se refiere a la jurisprudencia de oportunidad $^{55}$.

51 El Proyecto de Ley por el que se modifica la Ley Orgánica 10/1995, de 23 de noviembre, del Código penal, aprobado en Consejo de Ministros el 13 de noviembre de 2009, presenta un texto que modifica el art. 132.2 que no resuelve la polémica que existe en estos momentos sobre la prescripción del delito.

52 CERVANTES, Don Quijote, II, LI. Hay que tener en cuenta que el Código penal de 1985 se ha modificado en más de veinte ocasiones. Vid. SERRANO MAÍLLO y SERRANO GÓMEZ, «El aumento de la firmeza en la respuesta al delito al nivel legislativo en España (1995-2007)», en H. Kury y Serrano Maíllo (ed.), Punitividad y victimización en la experiencia contemporánea. Estudios, Madrid, 2009, págs. 291 y ss.

53 MANZANARES SAMANIEGO J. L., "La clasificación de las sentencias, en particular de las muy minoritarias que dictan algunos jueces para aligerar su esfuerzo y gozar de buena fama entre ignorantes y otras gentes de fácil contentar», en Actualidad penal, 2003-3, págs. 1167 y ss. Hace una clasificación de sentencias penales: circular, policíaca o a lo Ágata Christie, empanada, al descabello, polivalente, prefabricada, precocinada o de refrito, al gusto del chef, a la violeta, gratuita, al alicón, escolástica, lecho de Procusto, flamencas o colombinas, ladrillo, al nombre propio, Frankenstein, sentencia legislativa, al gerundio, al jurado español, sentencias cortas y sentencias largas, sonda, resurrection pie, porosa o de los vasos comunicantes, a la olla podrida, putativa, formulario y a la buena de Dios.

${ }^{54}$ MANZANARES SAMANIEGO, en ob cit., pág. 1169, escribe: «La sentencia "al gusto del chef" sirva más al lucimiento del juzgador - y al bien general- que a las exigencias de un supuesto concreto pero casual. Se rompen ataduras y se derrama doctrina, por vía de obiter dictum, en cuantas materias se estime conveniente. El "chef", que suele identificarse con el ponente de un tribunal colegiado, desviará sus razonamientos desde la línea argumental que el caso requiere hasta los problemas que le preocupan. Así, el ritmo de trabajo y el carácter accidental de esas consideraciones respecto al fallo facilitarán el sesgado acceso a la jurisprudencia de unas opiniones ajenas al debate. Un día, el valedor de aquella postura advertirá, cuando la cuestión se plantee por derecho, que ya existe abundante jurisprudencia sobre el particular. El sistema es propio de espíritus vanidosos, engreídos y escasamente fiables. Cabe, sin embargo, que sólo se trate de émulos de Juan Palomo, inclinados al juego discrecional de preguntas y respuestas seleccionados para asombro de curiales y otros juristas».

55 JORGE BARREIRO, A., «Jurisprudencia de oportunidad: el ocaso de la acción popular», en $J p D$, núm. 61/2008, págs. 9 y ss., escribe en pág. 15: «Lo más curioso de todo es que los mismos políticos que en no pocos casos jalean, apoyados por supuesto por alguno de los grupos mediáticos, la actuación de algunos jueces, después acaban afirmando que los jueces carecen de imparcialidad y de independencia de criterio para controlar las instrumentalizaciones del proceso por las acusaciones populares [...] El caso 
La desconfianza sobre la Administración de Justicia es una cuestión que ha calado en la opinión pública ${ }^{56}$. Los abogados también son críticos con el funcionamiento de la misma, ya se apuntó que su opinión sobre el Consejo General del Poder Judicial es negativa. En una encuesta realizada a 5.243 abogados de toda España sobre el actual modelo de la Administración de Justicia, el 88\% considera que está en una crisis muy grave y el $83 \%$ añade que no ha mejorado en los últimos años, o que ha empeorado ${ }^{57}$. Son letrados ejercientes en el área civil, penal, social y contencioso-administrativa ${ }^{58}$.

Que nadie confíe en una mejora medianamente eficaz de la Administración de Justicia. Tras el fiasco que crea la LOPJ de 1985 con el sistema en la propuesta de nombramiento de los miembros del Consejo General del Poder Judicial y las competencias que se le atribuyen, la supresión de la Justicia de distrito, el adelantamiento de la jubilación de los Magistrados a los 65 años para eliminar a los que no interesaban —edad que se eleva poco después_- para colocar a otros más dóciles, creación de nuevos sistemas de acceso a la carrera judi-

que ahora nos ocupa constituye un ejemplo de una asombrosa plasticidad descriptiva sobre lo que se acaba de exponer. Se trata de un supuesto en que los altos dirigentes de la entidad bancaria más importante del país y otros 28 ciudadanos han sido imputados por una serie de delitos en cadena que afectan fundamentalmente a la Hacienda Pública, es decir, al patrimonio común de los ciudadanos. Se transforma el procedimiento contra ellos. El Ministerio Fiscal y la Abogacía del Estado no acusan, y dos acusaciones populares sí lo hacen. La Juez de Instrucción y la Sala competente de la Audiencia Nacional — cuatro jueces en instancias distintas- sí encuentran indicios criminales contra los imputados. Y cuando, después de quince años, se está iniciando la vista oral del juicio, otra Sala distinta de la Audiencia Nacional implanta una nueva doctrina procesal que cercena a partir de ahora de forma capital la intervención autónoma de las acusaciones populares en más del noventa por ciento de los procesos penales. Por último, el Tribunal Supremo avala su decisión, muy preocupado, eso sí, por la desconfianza que muestran unos atrevidos y suspicaces ciudadanos hacia la intervención del Ministerio Fiscal como monopolizador de la acción penal».

56 En las encuestas del CSIC así se refleja. No obstante, hay que indicar que muchos critican la Administración de Justicia sin tener conocimiento de cómo funciona la misma, por lo que los datos que se obtienen son poco fiables. El diario El Mundo de 22 agosto 2008, en encuesta Sigma Dos cit, pág. 24 a la pregunta de ¿Cómo calificaría el funcionamiento de nuestra Justicia?, las respuestas son: muy bueno $(0,7 \%)$, bueno $(7,4 \%)$, normal $(28 \%)$, deficiente $(39,6 \%)$, muy deficiente $(22,3 \%)$, Ns/Nc $(2 \%)$.

57 Abogados. Revista del Consejo General de la Abogacía española, núm. 56, 2009, cit., pág. 6.

${ }_{58}$ A la pregunta de ¿Cómo diría usted que funciona en la actualidad la Administración de Justicia?, las respuestas fueron: bien (13\%), regular (15\%), mal (45\%), muy mal (26\%), Ns/Nc (1\%). A la pregunta en estos últimos años la situación de nuestra justicia ¿ha mejorado, ha empeorado o sigue más o menos como estaba?, las respuestas son: ha mejorado (15\%), ha empeorado (38\%), sigue como estaba $(45 \%)$, $\mathrm{Ns} / \mathrm{Nc}(2 \%)$. 
cial - tercero y cuarto turno-, exceso de jueces interinos ${ }^{59}$, politización, etc, se ha llegado a tal deterioro de la Justicia que para salir de la situación en la que se encuentra son necesarios muchos años con profundas reformas, que no se harán.

Tengo serias dudas de que exista verdadero interés en que se hagan reformas eficaces. Hay demasiado poder en juego y muchos intereses creados. Tenemos personas ocupando puestos importantes de libre elección al que por méritos nunca hubieran llegado. Hay políticos empeñados en influir en el sistema de selección de los jueces, estando entre sus metas el nombramiento de personas - con determinado perfil ideológico ${ }^{60}$ - aunque sean ignorantes en Derecho, para lo que cualquier procedimiento de selección es válido ${ }^{61}$. Hay diri-

59 REQUERO, en ob. cit., págs. 39 y ss. dice con respecto a los jueces sustitutos y magistrados suplentes que «para un año judicial puede haber nombrados más de mil quinientos entre una y otra categoría ... pero este mal no es atribuible al poder político: lo hemos generado los propios jueces ... esa recluta masiva de sustitutos se hace por órganos de gobierno elegidos por los propios jueces y formados exclusivamente por jueces ... Personalmente prefiero optar por recordar que el ciudadano tiene derecho a que la Justicia sea administrada por jueces profesionales ... Poco respeto podemos reclamar los jueces a la sociedad si consideramos que nuestra función puede hacerla el primero que pasa por la calle. Luego no vale lamentarse de que el poder político no nos respete o que opte por rebajar el nivel para ser juez mediante reclutas masivas, o con jueces de proximidad, si los propios jueces dicen que cualquiera vale» Esto sucede porque hay muchos intereses creados.

${ }^{60}$ REQUERO, ob. cit., págs. 43: «El objetivo político es, como digo, diseñar un sistema que permita seleccionar a los futuros jueces, no con arreglo a criterios de conocimientos jurídicos, sino por su perfil ideológico. Con la oposición, el porcentaje de jueces "políticamente comprometidos" no llega al 8 o 9 por ciento, y se trata de invertir el porcentaje».

${ }^{61}$ Un intento para nombrar jueces sin superar un sistema de oposición se recogía en el Proyecto de Ley Orgánica de modificación de la Ley 6/1985, de 1 de julio, del Poder Judicial, en materia de Justicia de proximidad y Consejos de Justicia (BOCG, Congreso de los Diputados, núm. 71-1, serie A de 27 enero 2006). Este Proyecto ha decaído ya que no se tramitó en la legislatura anterior. Se creaba una nueva figura de jueces, los «Jueces de proximidad». Se pretendía volver así a la antigua Justicia municipal que cumplió una función muy importante y su supresión por la LOPJ de 1985 ha creado serios problemas en la acumulación de asuntos en los Juzgados de Primera Instancia e Instrucción. Se introducía en este Proyecto un nuevo artículo en la LOPJ, el 301 bis, con la siguiente redacción: «El ingreso en la Carrera judicial, por la categoría de juez de proximidad, tendrá lugar mediante la superación de un concurso de méritos, entre juristas con más de seis años de ejercicio profesional, que cumplan los requisitos generales para el ingreso en la Carrera judicial...». En el apartado f) de este artículo se recogía: «Transcurridos nueve años como jueces de proximidad podrán ascender a la categoría de juez mediante concurso a las vacantes de esta categoría convocado por el Consejo General del Poder Judicial, previo informe favorable del Consejo de Justicia». De este Proyecto se desprende que el partido en el poder sigue con la idea de nombrar jueces sin exigir un sistema de oposición, o concurso-oposición. 
gentes de Comunidades Autónomas que están a la espera de tener la mayor competencia posible en materia de Justicia para tomar posiciones al respecto. De poco le vale a los jueces y magistrados organizar huelgas pidiendo más medios personales y materiales, que son necesarios, si se siguen nombrando jueces - y otro personal- sin la preparación y capacidad suficiente ${ }^{62}$. Podemos tener magníficos edificios con las mejores instalaciones, pero como no dispongamos de buenos jueces y funcionarios, o parte de aquellos estén politizados, nunca podremos tener una buena Justicia. La situación irá a peor.

La Administración de Justicia lo que necesita es una regeneración, no pequeñas reformas. Lo primero que hay que hacer es despolitizarla, a lo que no están dispuestos los partidos políticos; proteger y fortalecer la independencia de los jueces y buscar un sistema de selección que garantice su capacidad profesional, eliminando cualquier otro tipo de ingreso. El actual de oposición libre de acceso a la Escuela Judicial es por ahora el mejor; se incorporan jóvenes con vocación e ilusionados por la carrera; no me convencen los otros sistemas donde personas de más edad suelen buscar asegurarse un puesto de trabajo, a la vez que el sistema de acceso no ofrece garantías. Hay que terminar con la Justicia interina ${ }^{63}$; todos los jueces han de ser profesionales e independientes ${ }^{64}$. Hay que buscar la fórmula para que las ausencias por permisos, enfermedad, vacaciones, etc., sean suplidas por jueces de carrera. Los abogados prefieren un sistema

${ }^{62}$ En el mes de marzo de 2008 hubo una huelga por cuestiones salariales de funcionarios de los juzgados. El 21 de octubre de este año hubo un paro de tres horas de los secretarios judiciales como protesta a una sanción que se impuso a la secretaria de un Juzgado por el Ministerio de Justicia. El 8 de octubre de 2009 hubo otra huelga convocada por la Asociación Profesional de la Magistratura.

${ }^{63}$ REQUERO, en ob. cit., pág. 56 escribe: «Ya me he referido a la llamada "Justicia interina" o, para decirlo en pocas palabras, la recluta masiva por vía de contrato de licenciados - en no pocos casos de ignorada procedencia- para servir como jueces sustitutos y magistrado suplentes; es decir, no profesionales ni inamovibles. Si un licenciado en Derecho lee estas líneas, está en paro y no tiene excesivos escrúpulos, que se anime: puede, sin grandes problemas, ser contratado mediante cualquiera de estos sistemas, y así, tras hilvanar prórroga tras prórroga, a los diez años verá caer en su mano el fruto maduro, un nombramiento como magistrado titular por vía del cuarto turno. Esa "Justicia interina" encierra una verdadera judicatura en la sombra». Los Presidentes de los Tribunales Superiores de Justicia reunidos en Zaragoza en octubre de 2008 manifestaron su preocupación por la extrema gravedad que suponía que cada día era necesario más de 600 jueces sustitutos o magistrados suplentes para la celebración de juicios. Vid $A B C$ de 4 octubre 2008, pág. 27.

${ }^{64}$ DÍAZ HERRERA e Isabel DURÁN, en ob. cit., pág. 414 dicen: «Según el artículo 2, apartado 20 de la Declaración Internacional de la American Bar Association, la asociación de juristas más importante de Estados Unidos, "el nombramiento de jueces temporales es incompatible con la independencia judicial" ". 
mixto ${ }^{65}$, tal vez pensando en que algunos de ellos pueden pasar a formar parte de la carrera judicial. También hay que cambiar el sistema de dependencia jerárquica de la Fiscalía, que han de ser independientes como los jueces. Hay que hacer muchas cosas más. En el ámbito penal, por ejemplo, hay que reformar la Ley de Enjuiciamiento Criminal que permita, entre otras cosas, una mayor agilidad en los procedimientos ${ }^{66}$, cuestión que viene debatiéndose desde hace muchos años. Todavía no tenemos claro quien debe ser el instructor, si jueces o fiscales ${ }^{67}$; para que éstos se encarguen de la instrucción necesariamente hay que cambiar su sistema actual de dependencia jerárquica. De momento se pondrá algún parche, para dar la impresión de que se hace algo, pero no veremos por ahora ningún cambio importante. Lo probable es que todo siga deteriorándose. Es posible que llegue a desaparecer el Poder Judicial como tal, quedando el control de la justicia en manos de las autonomías y del Gobierno de turno.

${ }^{65}$ A la pregunta ¿cuál de las siguientes formas de selección a los nuevos jueces le parece mejor? Respuestas: un concurso de méritos entre juristas de reconocido prestigio $(16 \%)$, sistema que refunda los antiguos tercer, cuarto y quinto turnos $(6 \%)$, un sistema que combine las dos anteriores alternativas (73\%), Ns/Nc (5\%). Hay que tener en cuenta que el tercer y cuarto turno han fracasado. Los juristas de prestigio normalmente seguirán en su despacho que le es mucho más rentable que ser juez o magistrado. De otra parte, en un país como el nuestro donde la picaresca, los chanchullos, la corrupción, las influencias políticas y la falta de objetividad tiene el grave riesgo de nombrar jueces a quienes no están capacitados para ello, como ya ha sucedido en otras ocasiones.

${ }^{66}$ En la Ley 13/2009 de 3 noviembre (BOE, n. ${ }^{\circ} 286$ del 4) de reforma de la legislación procesal para la implantación de la Nueva Oficina Judicial modifica la Ley de Enjuiciamiento Criminal, ampliando las funciones de los secretarios judiciales.

67 LORCA NAVARRETE, A.M., «Hacia la instauración del juez de garantías en el proceso penal español y la desaparición del juez instructor», en La Ley, núm. 7158, 21 abril 2009, en pág. 2 escribe: «El futuro juez de garantías es un órgano jurisdiccional que no investiga y, por ende, está en una posición que le permite examinar imparcialmente la labor del fiscal y también la de la policía judicial. La conclusión no se hace esperar: la fase de investigación se judicializa en cuanto a su control, se evitan abusos y se presta rápido auxilio a los imputados en cuanto a los eventuales excesos o desequilibrios que se puedan producir. Y una necesidad ineludible; la instrucción y el instructor tal y como se conocen con la actual LECrim. han de desaparecer». 